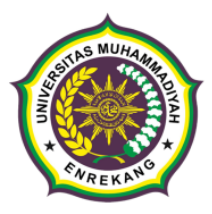

\title{
The Development of Multimedia Computer Graphics Learning in Supporting Learning during the Covid-19 Pandemic
}

\author{
Zulkifli $\mathbf{N}^{1}$, Handi Ferdiansyah ${ }^{2}$, Mardhatillah ${ }^{3}$ \\ 1 (Bisnis Digital, Universitas Muhammadiyah Sidenreng Rappang, Indonesia). \\ ${ }_{2}^{2}$ (Bisnis Digital, Universitas Muhammadiyah Sidenreng Rappang, Indonesia). \\ ${ }^{3}$ (administrasi Kesehatan, Universitas muhammadiyah Sidenreng Rappang, Indonesia).
}

* Corresponding Author. E-mail: ${ }^{1}$ zulkiflin73@gmail.com

\begin{tabular}{|l|l|l|}
\hline Receive: 17/08/2021 & Accepted: 23/08/2021 & Published: 01/10/2021
\end{tabular}

\begin{abstract}
The objectives of this research were, (1) to develop a prototype of multimedia learning in Computer Graphics course, (2) to test the validity, practicality, and effectiveness of learning multimedia developed in Computer Graphics course. This research was a Research and Development (R\&D) design with ADDIE model include thirty students as a sample. The procedure of this research until implementation stage. Instrument of the research was a questionnaire. Data of need analysis obtained based on the review of the exist curriculum, the characteristics of the materials and students need. The students need media that is not only in the conventional form of the file that just containing text but more than it, the media which is able to provide experience directly in the multimedia form that containing images, text, animation, and videos. The multimedia design of computer graphics learning is specifically designed from the structure, contents, menu placement, color selection, and so on to make it easier for lecturers and students. The results of this research are: (1) The results of the analysis of the data validity of the media are in the very valid category, this is obtained from the expert validation of material and media. (2) The results of the evaluation of the students' trials and the lecturers' responses to this multimedia are very practical. (3) this learning multimedia was effective as seen from the recapitulation of the pretest and post-test learning outcomes assessment showing a significant increase in student learning scores.
\end{abstract}

Keywords: Multimedia, Computer Graphics, Learning, Covid-19

\section{INTRODUCTION}

Education has an important role in the survival of a country's life. That is because education is a means to develop and improve the quality of human resources. The government made various efforts to improve the quality of the process and learning outcomes at every level and education unit. As stated in the 1945 Constitution, national development aims to educate the nation's life. As the spearhead of education, an educator is required to have the ability to organize learning, starting from planning in the form of concepts, implementing, evaluating, and improving learning systems or methods.

Theories about learning experiences or who are more familiar with the Dale's Cone of Experie nce put forward by Edgar Dale in Arsyad do not describe the level of difficulty of a lesson, but rather the abstractness and the number and types of senses used in the process of receiving messages or subject matter. Arsyad explained, this cone was a detailed elaboration of the concept of the three levels of experience put forward by Bruner, namely direct experience (enactive), pictorial/picture (iconic) 
experience, and abstract (symbolic) experience. First, a person begins to learn through direct (concrete) experience, then through artificial objects, to verbal (abstract) images.

This is supported by Law No. 14 of 2005 concerning Teachers and Lecturers, which states that "every teacher/lecturer must be able to utilize technology for the benefit of organizing educational development activities". Lecturers must be technology literate so that in the learning process they can utilize various technologies as media or learning resources.

The use of tools in the form of learning media will help the effectiveness of the learning process and delivery of messages and the content of learning materials. Many studies have proven that the use of instructional media is more effective and efficient in helping educators deliver learning messages so that students more easily understand the material delivered. It also has a positive effect and synergy that can change their attitudes and behavior to be creative and dynamic. Based on this, BSNP (2010) formulated that education in the 21st century must consider several aspects, namely, (1) the utilization of educational technology, (2) the strategic role of teachers/lecturers and students, (3) creative learning and teaching methods, (4) contextual teaching materials, and (5) individual-based independent curriculum structure. It is common knowledge that there are still many lecturers who have not utilized technology in learning, either due to inadequate facilities and infrastructure or the inability of lecturers to use technology. Knowledge is the result of knowing and occurs after people sense certain objects that are important in shaping one's behavior (Mardhatillah, Febrianti and ..., 2021). Software and hardware technology is used to communicate knowledge, skills, or attitudes to students so that students experience behavioral changes (Elihami and Saharuddin, 2018).

In general, the ability of lecturers/educators in using multimedia tools is very supportive of the learning process. The use of appropriate methods also determines the effective learning process. However, it cannot be denied that the classical learning method, that is the lecture method, has not yet been completely settled by the instructor in the learning process. Sagala (2010) states that "a lecture method is a form of interaction through verbal illumination and narration from teacher to student." This is caused by the lack of creativity of lecturers in the use of supportive learning media as a learning tool. Lecturers use books as learning resources and interactive media that are used are still limited to power points, this causes students to tend to be passive in the learning process, so only as recipients of information from lecturers. Monotonous computer graphic learning techniques, using verbal communication make students feel bored quickly. Multimedia learning has not been implemented in Computer graphics courses so that it causes a decrease in student motivation and learning interest. And the limited knowledge and creativity of lecturers in developing multimedia learning.

This problem is the background of researchers to conduct development research with the title "Development of multimedia computer graphics learning courses in the educational technology program of Universitas Muhammadiyah Sidenreng Rappang" in the hope that the contribution of this research can help develop creative, effective and enjoyable learning systems to make Muhammadiyah UNIVERSITAS Sidenreng Rappang is a superior campus.

\section{RESEARCH METHODS}

This type of research is research and development (research and development). The development model used in this study is the ADDIE model (Analysis, Design, Development, Implementation, and evaluation). Location and research subject, this research was conducted at Universitas Muhammadiyah Sidenreng Rappang, and the test subjects in this research and development consisted of content experts, media experts as well as lecturers and students as users of the developed products. The number of test 
subjects is one content expert, one media expert, one computer graphics lecturer, five individual trials and twenty-five small group trials.

Development procedures include: 1) Analysis This analysis aims to obtain information about the needs needed in developing learning media, such as media and literature used in Computer Graphics Courses during the pandemic COVID 19. Next, identify problems in learning and find solutions to those problems. The final step in this section is to formulate competencies that must be achieved by students after the learning process. 2) The design stage includes the selection of media design items presented, the preparation of the manuscript, the preparation of the flow of material delivery in the form of making media storyboards, and the collection of materials needed in media development. 3) Development stage there are 3 activities carried out by researchers, among others: product creation, validation (validation of material experts, validation of media experts) and revision. 4) Implementation phase which evaluates the product developed by conducting trials involving students and lecturers divided into individual trials, small group trials, lecturer responses and evaluation of learning outcomes. 5) The evaluation phase is not carried out by the researcher, because the researcher only reaches the effectiveness of the product being examined.

The collection of data used in this study are as follows: 1) Interviews, interviews in this study are aimed at lecturers in the subject of Computer graphics. Interviews with lecturers aim to explore information about the characteristics of the objectives, competency standards in computer graphics courses, as well as what material is urgent to develop into a learning medium. This interview also aims to identify the needs of students in learning, especially computer graphics courses. 2) Observation is carried out by the researcher jumping directly into the classroom where the researcher observes and interviews students while the teaching and learning process in the classroom takes place, an observation also serves to obtain empirical data to find out the implementation constraints in the actual learning process. 3) The questionnaire is used to know the responses of material experts, media, students, and lecturers regarding the development of multimedia learning that is done to determine the feasibility of the product as a basis for revising the product.

The data obtained in this study are qualitative and quantitative. Qualitative data obtained from criticism and suggestions obtained from the material validity test questionnaire, media validity test, and user trial questionnaire. The data is used in the process of improving and refining the media. While the quantitative data obtained from the scores obtained in the questionnaire, the quantitative data analysis technique used in this study is quantitative descriptive. Data analyzed included the validity of the material from the material experts, the validity of the media from the media experts and the responses of lecturers and students as the object of the trial.

The validity level of learning multimedia is determined based on the criteria for categorizing the quality of the media adapted from the categorization according to Azwar (2014) shown in table 3.5 below:

\section{Table 1 Validity Categories}

\begin{tabular}{ccc}
\hline No & Interval & Categori \\
\hline 1 & $3,5 \leq \mathrm{M}<4$ & Very valid \\
\hline 2 & $2,5 \leq \mathrm{M}<3,5$ & Valid \\
\hline 3 & $1,5 \leq \mathrm{M}<2,5$ & Fair enough \\
\hline 4 & $1,0 \leq \mathrm{M}<4$ & Invalid
\end{tabular}

Determination of the practicality level of learning multimedia, students, and lecturers as respondents who are directly involved in the trial process of learning multimedia products. The product trial consists of three stages, namely individual trials, small group trials, and lecturer responses in computer graphics courses. Trial of the respondent to obtain data as a basis for determining the level 
of practicality. Learning media are said to be practical if lecturers and students respond to the media minimally to the stated aspects. To state the practicality of multimedia-based learning media products based on observations adapted from categorization according to Azwar (2014) shown in table 3.6 below:

Table 2 Practical Categories

\begin{tabular}{ccc}
\hline No & Interval & Categori \\
\hline 1 & $3,5 \leq \mathrm{M}<4$ & Very practical \\
\hline 2 & $2,5 \leq \mathrm{M}<3,5$ & Practical \\
\hline 3 & $1,5 \leq \mathrm{M}<2,5$ & Quite practical \\
\hline 4 & $1,0 \leq \mathrm{M}<4$ & Not practical
\end{tabular}

The level of effectiveness can be seen from the success of developing multimedia to present material by the curriculum and can improve student learning outcomes seen from the results of pre-test and post-test learning. Post-test results must increase from pre-test results and grades above the minimum graduation limit where for computer graphics courses the minimum student graduation limit is 51 or grade $\mathrm{C}$.

\section{RESEARCH \\ RESULTS \\ AND \\ DISCUSSION \\ Research result}

Research on the development of multimedia learning in this computer graphics course, using the type of research and development (Research and Development) using ADDIE models that aim to produce multimedia computer learning multimedia that meets the requirements of validity, practical, and effective.

\section{Analysis}

The Analysis Phase is the initial stage in the research development of multimedia computer graphics learning. The analysis phase consists of needs analysis, analysis of student characteristics, analysis of basic competencies.
The needs analysis is done when the observation on campus is carried out by identifying the learning activities in the computer graphics course. Books are still the main source of learning and the interactive media used are still limited to power points. The learning process is still dominated by lecturers in the learning process so that learning is only a teacher center.

Analysis of student characteristics, at this stage students, have been able to think abstractly, reason logically and be able to determine what they like. Along with the times, began to bloom the use of developing technology, of course, students are more interested in applying new media in the learning process. With the development of learning multimedia that seems new according to them, it is very helpful and draws their attention to learning.

The basic competencies given to students are directed to be proficient in making graphic designs using Corel draw and photoshop applications. The adjustment of the content of the material in the media is adjusted to the modules used by the lecturer and directs students to be interested in the learning process.

Learning multimedia has many advantages that can display images, videos, texts, animations, and audio that can help students interact with learning resources. The characteristics of multimedia are being able to strengthen user responses quickly. Multimedia provides opportunities for students to choose and study independently. Multimedia has complete content and clear instructions, so users can use it without the guidance of others.

Multimedia learning that is developed can adjust the learning model desired by lecturers and can still be used to adjust the characteristics and needs of students.

The use of multimedia learning has a significant role in improving student learning outcomes. This is similar to Hamdani's opinion. (2011) in his book entitled Teaching and Learning Strategies states that "By paying attention to the complex and unique learning process, the accuracy of media selection and 
Jurnal Edumaspul, 5 (2), Year 2021- 339

(Zulkifli N, Handi Ferdiansyah, Mardhatillah)

learning methods will greatly affect student learning outcomes".

The results of needs analysis, student characteristics and competence can be concluded that students need multimedia learning that can stimulate and arouse student interest in learning and can be an alternative source of learning that can be used independently. $\mathrm{b}$. The design

Design is a follow-up to the analysis phase, planning multimedia learning tailored to the needs analysis that has been done at the analysis stage. At this stage of the analysis, there are various kinds of activities that must be carried out including 1) making flowcharts, 2) making storyboards.

Flowchart (flowchart) is a chart with certain symbols that describe the order of the process in detail. Flowcharts are used to help design multimedia learning and are useful for showing the flow of programs that will be made each part has a certain relationship. In this process, the researcher aims to determine the flow of multimedia programs to be made. Computer graphics course material obtained from RPS. The material presented in multimedia learning is graphic design using Corel draw and photoshop applications. The material was collected by researchers from various reference books, modules, and the internet. the results of the material collection are then arranged in the form of a flowchart.

Storyboards are made after the flowchart is complete, because this flowchart is used as a reference in making the storyboard. The storyboard is a sketch of images arranged in the sequence that is useful to facilitate the creation of multimedia learning flow.

The storyboard shows the initial multimedia design that will be developed such as the composition of the media, the position of the text, images, videos, and menus. The product developed is in the form of learning multimedia in which there are graphic design learning video tutorials.

c. Development Stage

In the design phase, a learning media procedural framework was compiled. while in the development stage, the framework which is still procedural is realized to become a product that is ready to be implemented. In the development phase, there are 3 activities carried out by researchers as follows: 1) making learning multimedia products, 2) validity of learning multimedia, 3) product revisions.

The stage of developing multimedia computer graphics learning products, the practicality of multimedia in the learning process.

Individual trials involving 5 students as respondents, to obtain data that can be used as a basis for obtaining practicality. For individual trials overall, an average score of 4.8 out of 16 assessment indicators is included in the very practical category.

Small group trials involving 25 students as respondents, small group trials get an average score of 4.8 out of 16 assessment indicators and fall into the very very practical category.

After getting the results of individual trials and small group trials, then multimedia graphics computer learning is responded by lecturers of the courses. The response of lecturers to multimedia learning that has been developed get a score of 57 from 12 assessment indicators, and obtain an average of 4.8. When referring to the practice table conversion table, multimedia learning is included in the very practical category.

Based on the results of student trials and lecturer responses that have been obtained, it is concluded that multimedia computer graphics learning that has been developed meets practical criteria and is suitable for use in the learning process in class.

The product effectiveness test is obtained from pre-test and post-test learning outcomes. Learning outcomes indicate that the average student pre-test learning outcomes are 66 and the average post-test learning outcomes are 94.8 This means that multimedia learning developed meets the criteria for effectiveness and is suitable for use in teaching and learning in the classroom because it can improve the learning outcomes of students in class A1 semester 3 of the 
Education Technology study program at FKIP Universitas Muhammadiyah Sidenreng Rappang.

Based on the results of the development in terms of the results of the test of validity, practicality, and effectiveness of multimedia learning is very easy to use by lecturers and students and can help lecturers and students in explaining and understanding learning material.

Thus the research and development of multimedia computer learning graphics profi educational technology Universitas Muhammadiyah Sidenreng Rappang get maximum results on the quality of instructional media that includes, valid, practical, and effective so that it is suitable for use in the process of learning computer graphics.

\section{Discussion}

Discussion of the results of research into the development of multimedia computer graphics learning includes 3 things, namely: 1) the results of research achieved, referring to the results of observations, learning documents, questionnaires, expert validation, student and lecturer trials. 2) the constraints that occur in the process of developing multimedia computer graphics learning. 3) Research weaknesses that limit field research.

The need for developing multimedia learning in this study was obtained from curriculum analysis and analysis of student characteristics. The developer then analyzes the material and media needs which show students the difficulty in understanding graphic design materials, while the media needs for students need media that do not only contain text, students are more interested in media that contains text, images, sounds, and videos that can provide explanations clearer and replayable material.

The findings obtained in this study are the production of computer graphics learning multimedia that is valid and suitable for use with very good criteria. Multimedia computer graphics learning has been said to be valid and feasible after going through the development process starting from the results of the needs analysis to the production stage which is then validated by material experts and media experts. The results of the material validation obtained a score that is in the category of very valid. Furthermore, the results of the validation by the media experts obtained a score that is in the category of very valid which means that the multimedia design of computer graphics learning developed has been by the material and needs of students.

The next stage is a trial run to obtain responses/ratings from lecturers and students. The results of the analysis of lecturers' responses to multimedia computer graphics learning obtained scores that were in the excellent category. Furthermore, through individual trials to 5 students, the scores were in the excellent category. While the small group trial of 25 students divided into 5 groups obtained scores that were in the excellent category. The next stage is to test the effectiveness of multimedia computer graphics learning on students through pre-test and post-test. A pre-test is conducted before students use learning multimedia created by the developer, the results of the pre-test still get less than the maximum value, this is also the basis for researchers to develop multimedia learning because it is considered by using multimedia students can get maximum value. Furthermore, a post-test test is performed on the post-test results, the average student gets the maximum score, it can be concluded that with multimedia learning can also improve student learning outcomes.

Based on the results of trials carried out namely from the validation of experts and field trials that measure the level of validity, practicality, and effectiveness of the use of learning multimedia, the learning multimedia is successfully implemented and meets the expectations of lecturers and students at FKIP Universitas Muhammadiyah Sidenreng Rappang.

The results of this study are supported by the opinion of Munir (2012) that the constraints in the product development process in this study were developed using the Macromedia flash application as the main 
program for creating multimedia learning. In the process of making computer graphics learning media requires a long time. In filling in the video tutorial sound that is in multimedia learning requires a good narrator, but it is difficult to find the right person to be a narrator in the video tutorial.

Weaknesses in the research process at Universitas Muhammadiyah Sidenreng Rappang have a weakness that is the lack of facilities such as projectors, projectors that exist in Universitas Muhammadiyah Sidenreng Rappang are still limited. This makes the lecturer constrained in teaching using multimedia learning, the means is supported in learning to use multimedia learning, because with complete facilities can maximize the learning process and the use of multimedia.

\section{CONCLUSIONS AND SUGESTION Conclusion}

Based on the results of the assessment and discussion carried out, the conclusion is drawn that:

1. Learning multimedia prototypes using Macromedia Flash 8 applications in computer graphics courses are learning multimedia in the form of animated graphics or graphic text that are equipped with sound files, video and image files from other applications. This media displays several menu options, including:

a. Info menu that contains information about media navigation

b. The introductory menu that contains learning outcomes, course learning outcomes, and semesters learning plans

c. Material menu

The material menu contains 5 meeting menus including 1) the first meeting contains the material definition of graphic design, the purpose of graphic design and the benefits of graphic design, 2) the second meeting contains material on typography and illustrations, 3) the third meeting contains material about color and layout, 4) the fourth meeting contains Corel draw material which explains about the menu menus contained in the Corel draw application and the functions of the menu besides that at the fourth meeting also contains a video tutorial for making logos, and 5) the fifth meeting contains material about photoshop which explains the menus on photoshop and explain the benefits of the menu, besides that there is also a video tutorial about making posters and video editing tutorial videos in increasing creativity during the covid 19 pandemic.

d. Problem menu

On the first appearance of the menu that is displayed is the instructions for the question then there is a column enter a name, where the column serves to load the name of the student who will work on the problem. After entering the name press the $\rightarrow$ button to start working on the questions, the questions contained in the problem menu are 30 multiple-choice questions. When the work on the questions has been completed, the number of scores obtained, the number of correct answers and the number of incorrect answers will appear. e. The exit menu functions to exit multimedia learning.

Menu options contained in multimedia computer graphics learning can be selected by using a pointer to enter the menu contained in multimedia.

2. The results of the analysis of computer graphics multimedia validation data are in the very valid category, this was obtained from the assessment of material experts and media experts.

3. Based on the evaluation of small group trial respondents and the lecturer's response to multimedia computer learning multimedia is included in the very practical category.

4. Multimedia computer graphics learning developed is included in the effective category as seen from the average recapitulation of student pre-test and post-test learning achievement scores showing an increase in student learning outcome scores.

Based on these conclusions, the multimedia computer graphics learning product is fit to be used as a learning medium for 3rd-semester students of class A1 of the FKIP Universitas Muhammadiyah Sidenreng Rappang education technology program. 
Jurnal Edumaspul, 5 (2), Year 2021- 342

(Zulkifli N, Handi Ferdiansyah, Mardhatillah)

\section{Suggestion}

Based on the results of the research discussion and conclusions can be suggested as follows:

1. It is hoped that this development program can be used as a program on campus to enable lecturers to develop learning media in other subjects.

2. It should not be implemented in one class or one campus so that they can see the benefits of the media on other campuses.

3. It is expected that the development of instructional multimedia will further develop learning media that cover one semester's material.

\section{BIBLIOGRAPHY}

Azwar, Saifuddin. 2014.Metode Penelitian. Yogyakarta: PustakaPelajar.

Badan Standar Nasional Pendidikan (2010). Paradigma Pendidikan Nasional di Abad-21. Jakarta: BSNP.

Dale, Edgar, 2002. Belajar untuk Hidup: Pendidikan Hari Ini dan Hari Esok. Jakarta: Bhatara Karya Aksara.

Elihami, E. and Saharuddin, A. (2018) 'Peran Teknologi Pembelajaran Islam Dalam Organisasi Belajar', Edumaspul Jurnal Pendidikan, 1(1), pp. 1-8. doi: 10.33487/edumaspul.v1i1.34.

Hamdani, 2011. Strategi belajar mengajar. Bandung: Pustaka Setia.

Mardhatillah, M., Febrianti, D. and ... (2021) 'Hubungan Pengetahuan Siswa tentang HIV dan AIDS dengan STIGMA Terhadap ODHA di SMAN 5 Makassar', Edumaspul: Jurnal ..., 5(1), pp. 451-457.

Munir. (2012). Multimedia Konsep \& Aplikasi dalam Pendidikan. Bandung : Alfabeta.
PendidikanNasional No. 16 tahun 2007 tentangStandarKualifikasiAkademikd anKompetensi Guru.

Sagala, Syaiful. 2010. Konsep dan Makna Pembelajaran. Bandung: Alfabeta.

Undang-undang No. 14 tahun 2005 Tentang Guru danDosen.

\section{Profil Penulis}

Penulis pertama Zulkifli N, S.Pd., M.Pd. penulis lahir di Ciro-ciroe,27 juni 1993. Pendidikan sarjana ditempuh penulis di Sekolah Tinggi Keguruan dan Ilmu Muhammadiyah Rappang Program Studi Teknologi Pendidikan dan selesai pada tahun 2016. Pada jenjang magister, penulis melanjutkan pendidikandi Universitas Negeri Makassar dengan prodi Teknologi Pendidikan selesai pada tahun 2020. Saat ini penulis tercatat sebagai dosen di Universitas Muhammadiyah Sidenreng Rappang.

Penulis kedua yaitu Handy Ferdiansyah, S.Pd., M.Pd. penulis lahir di Ujungpandang, 01 Januari 1988. Pendidikan sarjana ditempuh penulis di Sekolah Tinggi Keguruan dan Ilmu Muhammadiyah Rappang Program Studi Teknologi Pendidikan. Pada jenjang magister,penulis melanjutkan pendidikandi Universitas Negeri Makassar dengan prodi Teknologi Pendidikan. Saat ini penulis tercatat sebagai dosen di Universitas Muhammadiyah Sidenreng Rappang.

Penulis ketiga Mardhatillah, S.KM., M.Kes., lahir di Pinrang, 17 Mei 1992. Pendidikan Sarjana di tempuh penulis di Universitas Hasanuddin dengan mengambil Jurusan Epidemiologi, Fakultas Kesehatan Masyarakat tahun 2010.Pada jenjang Magister, penulis melanjutkan pendidikannya di Universitas Hasanuddin pada Program Kesehatan Masyarakat tahun 2016. Saat ini penulis tercatat sebagai dosen di Universitas Muhammadiyah Sidenreng Rappang, program studi Administrasi Kesehatan. 